\title{
The Decision in Ferrazzini: Time to Reconsider the Application of the European Convention on Human Rights to Tax Matters
}

\author{
Philip Baker, Gray's Inn Tax Chambers, London, Great Britain
}

In the June-July issue of this journal I wrote an article entitled 'Should Article 6 ECHR (Civil) Apply to Tax Proceedings?'. That article referred to the forthcoming decision of the European Court of Human Rights in the case of Ferrazzini $v$ Italy. ${ }^{1}$ The decision of the Grand Chamber of the Court was issued on 12 July 2001.

On the central issue of whether or not the guarantees for a fair trial in civil proceedings applied to tax litigation, the Grand Chamber of seventeen judges split. A majority of eleven judges decided that Art. 6 (Civil) did not apply to tax litigation: a substantial minority of six judges was prepared to depart from the prior jurisprudence of the Court and Commission and hold that the civil guarantees did apply to tax litigation. ${ }^{2}$

Those who have read my previous article will not be surprised to learn that I disagree with the decision of the majority and agree with the minority of judges. The majority approached the question on the historical basis that the draftsmen of the European Convention intended to exclude public law litigation from Art. 6 . They then considered whether litigation over the existence and quantum of a tax liability fell within this excluded category of public law litigation. They concluded as follows:

'The Court considers that tax matters still form part of the hard core of public-authority prerogatives, with the public nature of the relationship between the taxpayer and the tax authority remaining predominant. ... It considers that tax disputes fall outside the scope of civil rights and obligations, despite the pecuniary effects which they necessarily produce for the taxpayer.'

The minority, however, looked in somewhat greater depth at the travaux préparatoires to decide what type of public law dispute the draftsmen of the Convention intended to exclude from Art. 6. They noted that, with regard to a number of matters, the Court and Commis- sion had, over the years, changed its viewpoint and decided that these disputes fell within the civil protections in Art. 6. They concluded that it was now time to recognize that tax disputes should no longer be excluded from the Art. 6 protections. Unfortunately, they were unable to persuade sufficient of their colleagues to agree with them on this (to my mind) obvious point.

In the short term, the law as declared by Strasbourg remains the same: ordinary tax proceedings for the determination of the existence or quantum of a tax liability remain outside the fair trial protections in Art. 6 of the Convention. National courts in Member States of the Council of Europe are not necessarily obliged to follow this interpretation: national authorities including courts - may interpret the Convention to give greater protection to citizens than would be granted by Strasbourg; they may not give lesser protection than Strasbourg would require.

In the longer term, the issue will clearly need to be relitigated (unless the Convention is amended in the meantime). In the Ferrazzini case, the tax proceedings had already continued for almost fourteen years without being resolved at the time of the European Court's judgment. Similarly egregious breaches of human rights are not uncommon in other countries of the Council of Europe and are likely to be contested. It is notable in this context that the taxpayer in the Ferrazzini case was not legally represented before the Court in Strasbourg. Though there is little doubt that the judges of the Grand Chamber had access to relatively extensive research when preparing their judgments, it is still somewhat unacceptable that an issue of this importance should have been decided with representation only on one side.

At least for the present, the taxpayer in ordinary tax litigation has no right to a fair trial under Art. 6 of the Convention. In the absence of any equivalent protections under the constitutional or administrative law of the country concerned, the taxpayer has no right to:

\section{Notes}

2 There is no obvious explanation for the way in which the judges split. The eleven judges in the majority included judges from Switzerland, Sweden, Germany, France, Spain, Italy, Lithuania, Turkey, Norway, Hungary and Georgia. The minority of six judges consisted of the judges from Greece, Malta, Slovakia, Romania, Denmark and Luxembourg. 
- a determination within a reasonable time;

- access a court;

- a public hearing;

- an independent and impartial tribunal (although it seems pretty inconceivable that the constitutional or administrative law in the country concerned does not guarantee this);

- the protections regarding publicity and public access contained in Art. 6.

In practice, it is the lack of a right to a determination within a reasonable time which is probably of most concern to taxpayers in some countries.

One practical consequence of this decision is likely to be a further extension of the criminal aspects of Art. 6 to tax proceedings. The European Court has already established that the determination of a liability to substantial penalties for incorrectly completed tax returns involves the determination of a criminal charge, and all the criminal guarantees in Art. 6 will then apply. The issue of which tax penalties involve a criminal charge is gradually being clarified. There may also be a tendency in some countries for taxpayers to ask for the determination of their tax liability and the determination of any penalties to be considered at the same court hearing: in those circumstances, the Court has held that it is not possible to separate out the different parts of the proceedings and that Art. 6 applies to the entire proceedings. ${ }^{3}$ One of the bizarre consequences of the decision in Ferrazzini is that Art. 6 will apply in those countries where penalties and liability to tax are determined at the same time, but not in those countries were the determinations are separate.

Overall, one might say that the decision in Ferrazzini confirms that the dishonest taxpayer enjoys the full protection of Art. 6 while the taxpayer who is honestly seeking to dispute his tax liability has no right to a fair trial under the European Convention system.

Ferrazzini illustrates a wider point: that is, the need to review the application of the European Convention on Human Rights to taxpayers. It is clear that the draftsmen of the European Convention did not have tax matters within their sights when they sat down to draft the Convention. ${ }^{4}$ Tax proceedings differ from the criminal proceedings or civil litigation which the draftsmen had in mind when they put pen to paper. In tax proceedings, for example, there is the unusual situation that virtually all of the information is accessible only to the taxpayer, and the revenue authority relies upon information from the taxpayer to determine tax liability.

It is an obvious point to make that if you apply a Convention which was drafted with somewhat different proceedings in mind, the results you are likely to reach may not be wholly appropriate: they may in fact be somewhat perverse. It is somewhat perverse that the Strasbourg organs have determined that the criminal protections apply to tax penalty proceedings. It is a perverse consequence that the taxpayer then enjoys a right to silence in dealing with the revenue authority. ${ }^{5}$ It is a perverse consequence that, where a tax avoider has died, the penalties cannot be extracted from his estate. $^{6}$ It is now equally perverse for the European Court of Human Rights to conclude in Ferrazzini that the taxpayer has no right to a fair trial when he contests his tax liability.

What all this points to is that it is now high time that the Council of Europe reviewed the application of the European Convention to tax matters. The Convention is now becoming increasingly important in tax proceedings, and these perverse results are beginning to have undesirable consequences for the conduct of tax collection and tax proceedings. The objective of the Council of Europe should be to prepare a protocol adapting the European Convention to protect taxpayers. Such work is becoming urgent. One small plea: this work should be handed over to general experts on human rights, assisted by tax professionals and with input from tax administrators; it should not be left to tax administrations to carry out this review.

\section{Notes}

See the decision in Georgiou v. United Kingdom (Application No.40042/98) - decision of 16th May 2000.

4 There is an excellent and highly readable new book on this history of the European Convention from a UK point of view: see Brian Simpson, Human Rights and the End of Empire (Oxford, 2000).

See, for example, JB v. Switzerland (Application No. 31827/96) - decision of 3rd May, 2001

See the decisions in AP, MP and TP v. Switzerland (Application No. 19958/92) and the decision in EL, RL, and J-OL v. Switzerland (Application No. 20919/92). 